\title{
Assessment of Continuous (Unconventional) Oil and Gas Resources in the Late Cretaceous Mancos Shale of the Piceance Basin, Uinta-Piceance Province, Colorado and Utah, 2016
}

\author{
Using a geology-based assessment methodology, the U.S. Geological Survey assessed technically recoverable mean resources of \\ 74 million barrels of shale oil, 66.3 trillion cubic feet of gas, and 45 million barrels of natural gas liquids in the Mancos Shale of \\ the Piceance Basin in Colorado and Utah.
}

\section{Introduction}

The U.S. Geological Survey (USGS) completed a geology-based assessment of the continuous (unconventional) oil and gas resources in the Late Cretaceous Mancos Shale within the Piceance Basin of the Uinta-Piceance Province (fig. 1). The previous USGS assessment of the Mancos Shale in the Piceance Basin was completed in 2003 as part of a comprehensive assessment of the greater UintaPiceance Province (U.S. Geological Survey Uinta-Piceance Assessment Team, 2003). Since the last assessment, more than 2,000 wells have been drilled and completed in one or more intervals within the Mancos Shale of the Piceance Basin (IHS Energy Group, 2015). In addition, the USGS Energy Resources Program drilled a research core in the southern Piceance Basin that provided significant new geologic and geochemical data that were used to refine the 2003 assessment of undiscovered, technically recoverable oil and gas in the Mancos Shale.

\section{Geologic Summary of the Mancos Shale in the Piceance Basin}

The Late Cretaceous Mancos Shale was deposited within a foreland basin setting during the initial development and ultimate extension of the Cretaceous Western Interior Seaway. At its maximum extent, the Western Interior Seaway spanned from the present-day Arctic Ocean in the north to the Gulf of Mexico in the south, to central Utah in the west, and as far east as western Minnesota.

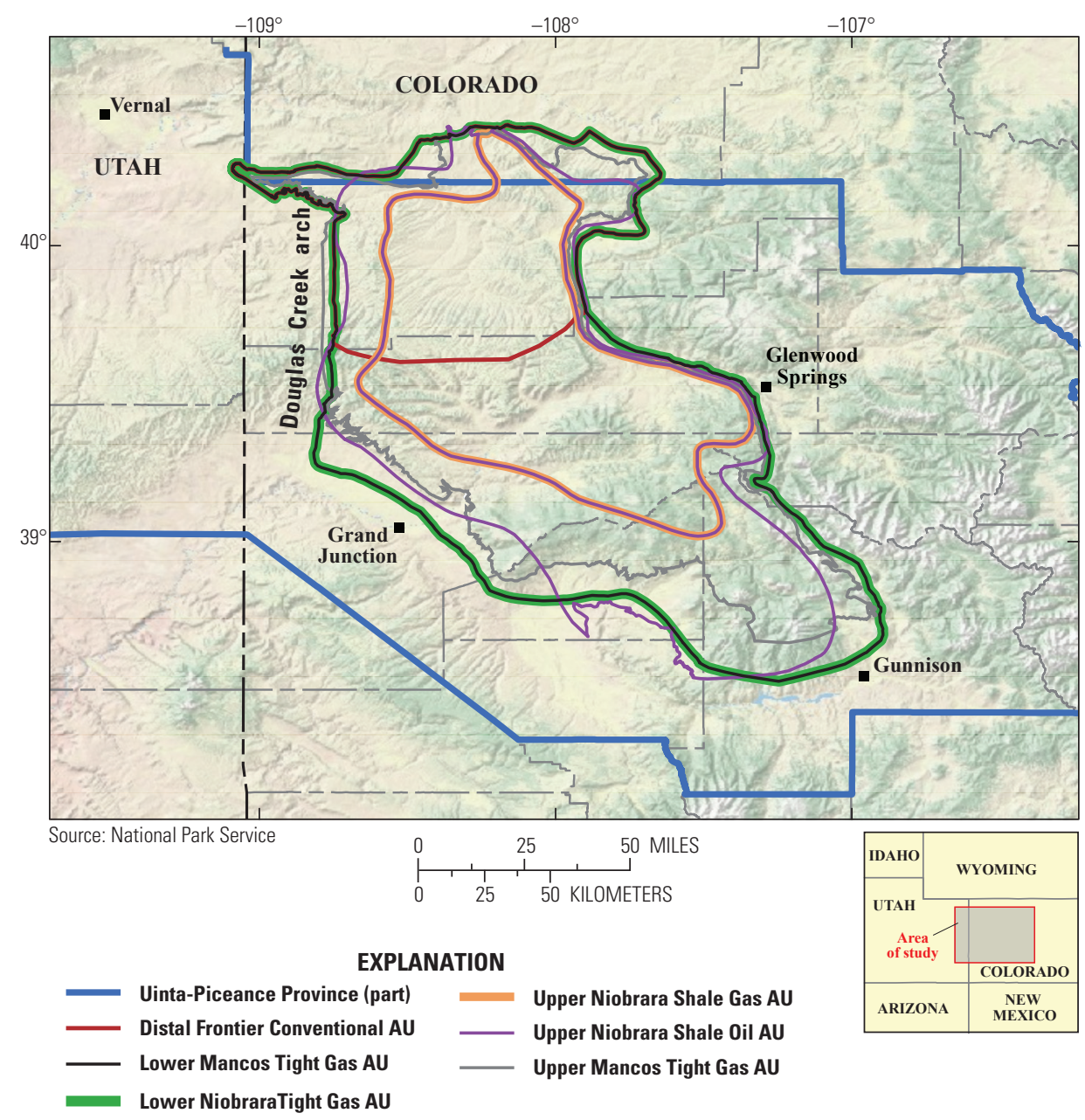

Figure 1. Map of the Uinta-Piceance Province and extent of six Mancos Shale assessment units. (AU, assessment unit)

The central part of the foreland basin was later segmented into multiple Rocky Mountain basins, including the Piceance Basin, during the Laramide orogeny. The Mancos Shale in the Piceance Basin represents more than 29 million years of deposition (Cobban and others, 1994). The unit is more than 4,000 feet thick throughout most of the basin and is dominated by mudrocks with varying amounts of terrigenous siliciclastic and biogenic calcite deposited in an offshore marine 
setting. The percentage of biogenic calcite in the Mancos Shale is highest in the lower half of the formation (Johnson and Rice, 1990). Organic matter is also highest in the lower half, consisting of Type II and mixed Type II/III kerogen with as much as 4.9 weight percent total organic matter (Johnson and Rice, 1990; Hawkins and others, 2012). In the upper half of the Mancos Shale, discontinuous siltstone and sandstone bodies represent distal to proximal shoreface deposits (Kirschbaum, 2003).

\section{Geologic Model for Assessment}

The primary hydrocarbon source rock for the Mancos/Mowry Total Petroleum System (TPS) is the Mancos Shale. Hydrocarbons generated in the Mancos Shale have migrated into tight (that is, continuous) reservoirs within the formation and into conventional reservoirs both above and below the formation. Tight reservoirs within the Mancos Shale include (1) offshore marine siltstones and sandstones in the basal members of the Mancos Shale; (2) sandstones and siltstones of the distal shoreface to tidally influenced Prairie Canyon Member (Cole and others, 1997), including the Mancos “ $B$ ” zone of Kopper (1962); and (3) shoreface sandstones in the upper Mancos Shale and Late Cretaceous Iles Formation. Mancos Shale gas also migrated into conventional reservoirs in the Piceance Basin along the Douglas Creek arch (Lillis and others, 2003). Hydrocarbons were also generated and retained within the calcareous, organic-rich Niobrara Member in the lower part of the Mancos Shale.

Tight gas in the younger, shallower Mancos Shale intervals is produced primarily from vertical and directional wells in which the reservoirs have been hydraulically fractured. The tight-gas production is reported as commingled production with the overlying Williams Fork Formation. Tight gas and continuous oil and gas in the older and deeper intervals of the Mancos Shale are produced mostly from horizontal wells that have been hydraulically fractured.

\section{Assessment Units}

The Late Cretaceous Mancos Shale was assessed previously as a single interval. The assessment combined all of the continuous accumulation resources within the Mancos and Mowry Shales into one set of three assessment units (AUs) that addressed the hydrocarbon resources in the entirety of the UintaPiceance Province (Kirschbaum, 2003). This current assessment of the Mancos Shale differs from the previous assessment in two ways: (1) it only assesses the Mancos Shale within the Piceance Basin and (2) the Mancos Shale strata are subdivided vertically into separate AUs. Each AU differs in geological characteristics that control hydrocarbon accumulation type and extent, the type of drilling and completion techniques applied, and the distribution of estimated ultimate recovery volumes of producing wells. These key factors influenced the input data used to assess the technically recoverable hydrocarbons in the Mancos Shale (table 1).

Five continuous AUs were defined in the Piceance Basin Mancos Shale for this assessment of the Mancos/ Mowry TPS: (1) Lower Mancos Tight Gas AU, (2) Lower Niobrara Tight Gas AU, (3) Upper Niobrara Shale Gas AU, (4) Upper Niobrara Shale Oil AU, and (5) Upper Mancos Tight Gas AU (fig. 1). One conventional AU, the Distal Frontier Conventional AU, was also identified but was not
Table 1. Key assessment input data for five continuous assessment units in the Mancos Shale, Piceance Basin.

[AU, assessment unit; \%, percent; EUR, estimated ultimate recovery per well; BCFG, billion cubic feet of gas; MMBO, million barrels of oil. The average EUR input is the minimum, median, maximum, and calculated mean. Shading indicates not applicable]

\begin{tabular}{|c|c|c|c|c|}
\hline \multicolumn{5}{|c|}{ Assessment input data-Continuous AUs } \\
\hline Lower Mancos Tight Gas AU & Minimum & Mode & Maximum & Calculated mean \\
\hline Potential production area of AU (acres) & 50,000 & $1,550,000$ & $4,651,000$ & $2,083,667$ \\
\hline Average drainage area of wells (acres) & 100 & 160 & 220 & 160 \\
\hline Success ratio $(\%)$ & 30 & 60 & 90 & 60 \\
\hline Average EUR (BCFG) & 0.08 & 0.6 & 1.2 & 0.622 \\
\hline AU probability & 1.0 & & & \\
\hline Lower Niobrara Tight Gas AU & Minimum & Mode & Maximum & Calculated mean \\
\hline Potential production area of AU (acres) & 50,000 & $2,000,000$ & $4,651,000$ & $2,233,667$ \\
\hline Average drainage area of wells (acres) & 100 & 160 & 220 & 160 \\
\hline Success ratio $(\%)$ & 60 & 85 & 95 & 80 \\
\hline Average EUR (BCFG) & 0.4 & 0.7 & 1.7 & 0.753 \\
\hline AU probability & 1.0 & & & \\
\hline Upper Niobrara Shale Gas AU & Minimum & Mode & Maximum & Calculated mean \\
\hline Potential production area of AU (acres) & 50,000 & $1,000,000$ & $3,800,000$ & $1,616,667$ \\
\hline Average drainage area of wells (acres) & 100 & 160 & 220 & 160 \\
\hline Success ratio $(\%)$ & 60 & 85 & 95 & 80 \\
\hline Average EUR (BCFG) & 0.5 & 0.8 & 2.6 & 0.901 \\
\hline AU probability & 1.0 & & & \\
\hline Upper Niobrara Shale Oil AU & Minimum & Mode & Maximum & Calculated mean \\
\hline Potential production area of AU (acres) & 5,000 & $1,000,000$ & $2,000,000$ & $1,001,667$ \\
\hline Average drainage area of wells (acres) & 100 & 160 & 220 & 160 \\
\hline Success ratio $(\%)$ & 10 & 30 & 75 & 38.33 \\
\hline Average EUR (MMBO) & 0.01 & 0.03 & 0.08 & 0.032 \\
\hline AU probability & 0.95 & & & \\
\hline Upper Mancos Tight Gas AU & Minimum & Mode & Maximum & Calculated mean \\
\hline Potential production area of AU (acres) & $2,220,000$ & $2,800,000$ & $3,742,000$ & $2,914,000$ \\
\hline Average drainage area of wells (acres) & 10 & 20 & 40 & 23.33 \\
\hline Success ratio $(\%)$ & 80 & 92 & 94 & 88.67 \\
\hline Average EUR (BCFG) & 0.15 & 0.4 & 0.65 & 0.408 \\
\hline AU probability & 1.0 & & & \\
\hline
\end{tabular}


Table 2. Assessment results for continuous and conventional oil and gas resources in the Mancos Shale, Piceance Basin.

[TPS, total petroleum system; AU, assessment unit; MMBO, million barrels of oil; BCFG, billion cubic feet of gas; NGL, natural gas liquids; MMBNGL, million barrels of natural gas liquids. Results shown are fully risked estimates. For gas accumulations, all liquids are included under the NGL category. F95 represents a 95 percent chance of at least the amount tabulated. Other fractiles are defined similarly. Fractiles are additive under the assumption of perfect positive correlation. Shading indicates not applicable]

\begin{tabular}{|c|c|c|c|c|c|c|c|c|c|c|c|c|c|c|}
\hline \multirow{3}{*}{$\begin{array}{l}\text { Total petroleum system (TPS) } \\
\text { and assessment units (AUs) }\end{array}$} & \multirow{3}{*}{$\begin{array}{c}\text { AU } \\
\text { prob- } \\
\text { ability }\end{array}$} & \multirow{3}{*}{$\begin{array}{c}\text { Accu- } \\
\text { mula- } \\
\text { tion } \\
\text { type }\end{array}$} & \multicolumn{12}{|c|}{ Total undiscovered resources } \\
\hline & & & \multicolumn{4}{|c|}{ Oil (MMBO) } & \multicolumn{4}{|c|}{ Gas (BCFG) } & \multicolumn{4}{|c|}{ NGL (MMBNGL) } \\
\hline & & & F95 & F50 & F5 & Mean & F95 & F50 & F5 & Mean & F95 & F50 & F5 & Mean \\
\hline & & & \multicolumn{12}{|c|}{ Mancos/Mowry TPS } \\
\hline Lower Mancos Tight Gas AU & 1.0 & Gas & & & & & 1,266 & 4,343 & 10,297 & 4,875 & 1 & 3 & 10 & 4 \\
\hline Lower Niobrara Tight Gas AU & 1.0 & Gas & & & & & 2,482 & 7,837 & 16,366 & 8,441 & 1 & 6 & 16 & 7 \\
\hline Upper Niobrara Shale Gas AU & 1.0 & Gas & & & & & 1,875 & 6,360 & 15,659 & 7,268 & 1 & 5 & 15 & 6 \\
\hline Upper Niobrara Shale Oil AU & 0.95 & Oil & 0 & 64 & 175 & 74 & 0 & 71 & 218 & 86 & 0 & 4 & 14 & 5 \\
\hline Upper Mancos Tight Gas AU & 1.0 & Gas & & & & & 28,498 & 43,773 & 69,129 & 45,661 & 6 & 21 & 44 & 23 \\
\hline $\begin{array}{l}\text { Total undiscovered } \\
\text { continuous resources }\end{array}$ & & & $\mathbf{0}$ & 64 & 175 & 74 & 34,121 & 62,384 & 111,669 & 66,331 & 9 & 39 & 99 & 45 \\
\hline Distal Frontier Conventional AU & \multicolumn{14}{|c|}{ Not quantitatively assessed } \\
\hline $\begin{array}{l}\text { Total undiscovered continuous } \\
\text { and conventional resources }\end{array}$ & & & $\mathbf{0}$ & 64 & 175 & 74 & 34,121 & 62,384 & 111,669 & 66,331 & 9 & 39 & 99 & 45 \\
\hline
\end{tabular}

quantitatively assessed. The Distal Frontier Conventional AU is hypothetical and defined by the presence of the Frontier Sandstone where it interfingers with the Mancos Shale as determined by examination of well logs.

The Lower Mancos Tight Gas AU includes tight-gas reservoirs in the Mowry Shale (where present) and in the Mancos Shale above the Dakota Sandstone and below the Niobrara Member of the Mancos Shale. The AU boundary is defined by the outcrop of the Mancos Shale to the north, east, and south, and along the axis of the Douglas Creek arch to the west (fig. 1).

The Lower Niobrara Tight Gas AU includes the bioturbated siliciclastic interval in the basal 250-400 feet of the Niobrara Member. The geographic extents of the Lower Niobrara Tight Gas $\mathrm{AU}$ and the Lower Mancos Tight Gas AU are the same.

The Upper Niobrara Shale Gas AU and Upper Niobrara Shale Oil AU include the portion of the Niobrara Member that is rich in organic matter and biogenic calcite (Hawkins and others, 2012). The AU boundaries were drawn using mapped vitrinite reflectance values from the base of the Mancos Shale. Vitrinite reflectance values between 0.6 percent and 1.35 percent (Peters and Cassa, 1994) were used to define the Upper Niobrara Shale Oil AU.
Vitrinite reflectance values greater than 1.35 percent (Peters and Cassa, 1994) were used to define the Upper Niobrara Shale Gas AU.

The Upper Mancos Tight Gas AU consists of proximal to distal shoreface deposits and offshore marine sandy siltstones in the upper Mancos Shale and the Iles Formation above the Niobrara Member and below the Williams Fork Formation. Gas production from the Upper Mancos Tight Gas AU is commonly reported as commingled with production from the overlying Williams Fork Formation. The Upper Mancos Tight Gas AU boundary was drawn on the outcrop of the Iles Formation.

\section{Resource Summary}

The U.S. Geological Survey (USGS) assessed undiscovered, technically recoverable continuous (unconventional) oil and gas resources in the Mancos Shale of the Piceance Basin (table 2). The USGS estimated mean volumes of 66.3 trillion cubic feet of gas, 74 million barrels of oil, and 45 million barrels of natural gas liquids in the Mancos/ Mowry Total Petroleum System. All of the undiscovered hydrocarbon resources quantitatively assessed are continuous (unconventional) reservoirs. The Distal Frontier Conventional Assessment Unit was not quantitatively assessed.

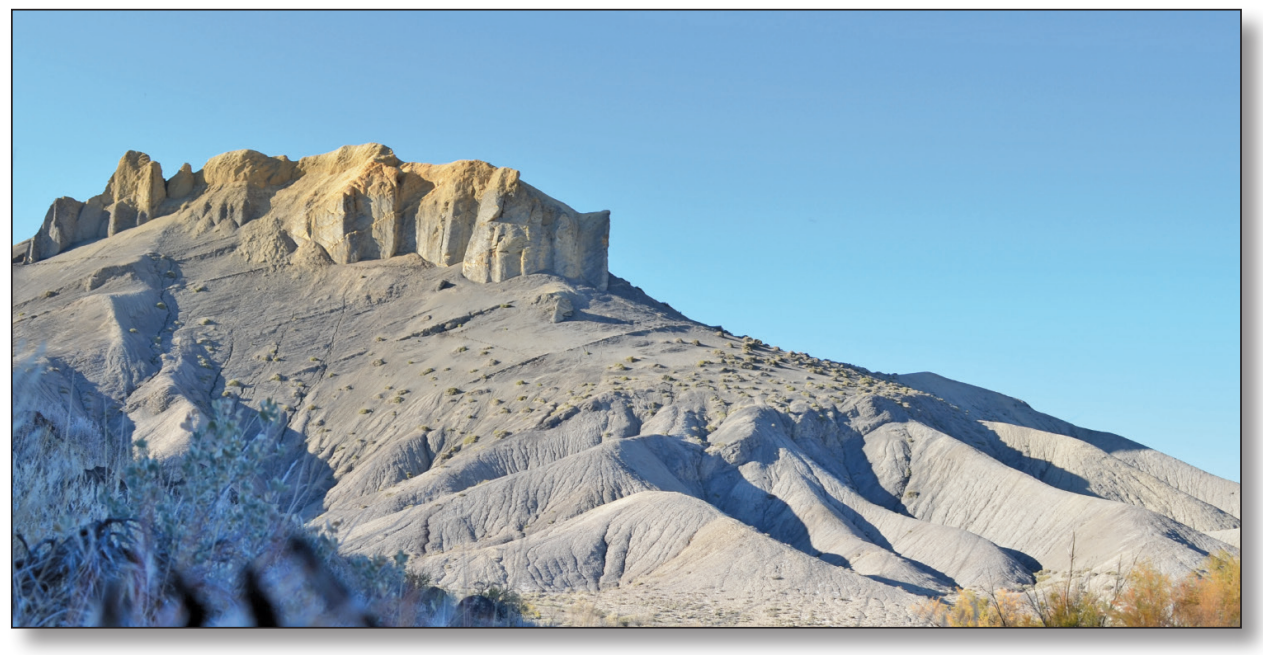

Outcrop of the Niobrara Member of the Mancos Shale known as The Castle, near Delta, Colorado. Photograph by Joshua Hicks, U.S. Geological Survey. 


\section{Acknowledgments}

The authors thank David Noe

(Colorado Geological Survey),

Gus Gustason (Enerplus Resources), Mark

Kirschbaum (USGS, retired), and Steve

Sonnenberg and Kathy Emme (Colorado

School of Mines) for all their assistance and guidance throughout this work.

\section{References}

Cobban, W.A., Merewether, E.A., Fouch, T.D., and Obradovich, J.D., 1994, Some Cretaceous shorelines in the western interior of the United States, in Caputo, M.V., Peterson, J.A., and Franczyk, K.J., eds., Mesozoic systems of the Rocky Mountain region, USA: Denver, Colo., Society of Economic Paleontologists and Mineralogists (Society for Sedimentary Geology), Rocky Mountain Section, p. 393-414.

Cole, R.D., Young, R.G., and Willis, G.C., 1997, The Prairie Canyon Member, a new unit of the Upper Cretaceous Mancos Shale, west-central Colorado and east-central Utah: Utah Geological Survey Miscellaneous Publication no. $97-4,23 \mathrm{p}$.
Hawkins, Sarah; Kirschbaum, Mark; and Schenk, Christopher, 2012, U.S. Geological Survey research core of the Niobrara Member of the Mancos Shale, Delta, Colorado [abs.], in American Association of Petroleum Geologists Rocky Mountain Section Meeting Program Abstracts, Grand Junction, Colo., September 9-12, 2012, p. 27.

IHS Energy Group, 2015, Petroleum information database: Available from IHS Energy, 15 Inverness Way East, Englewood, Colo., 80112.

Johnson, R.C., and Rice, D.D., 1990, Occurrence and geochemistry of natural gases, Piceance Basin, northwest Colorado: American Association of Petroleum Geologists Bulletin, v. 74, no. 6, p. 805-829.

Kirschbaum, M.A., 2003, Geologic assessment of undiscovered oil and gas resources of the Mancos/Mowry Total Petroleum System, Uinta-Piceance Basin Province, Utah and Colorado, chap. 6 of U.S. Geological Survey Uinta-Piceance Assessment Team, comps., Petroleum systems and geologic assessment of oil and gas in the Uinta-Piceance Province, Utah and Colorado (ver. 1.0) [CD-ROM]: U.S. Geological Survey Digital Data Series DDS-69-B, 51 p.
Kopper, P.K., 1962, Douglas Creek anticline and adjoining area, in Amuedo, C.L., and Mott, M.R., eds., Exploration for oil and gas in northwestern Colorado: Rocky Mountain Association of Geologists, p. 108-110.

Lillis, P.G., Warden, Augusta, and King, J.D., 2003, Petroleum systems of the Uinta and Piceance BasinsGeochemical characteristics of oil types, chap. 3 of U.S. Geological Survey UintaPiceance Assessment Team, comps., Petroleum systems and geologic assessment of oil and gas in the Uinta-Piceance Province, Utah and Colorado (ver. 1.0) [CD-ROM]: U.S. Geological Survey Digital Data Series DDS-69-B, 51 p.

Peters, K.E., and Cassa, M.R., 1994, Applied source rock geochemistry, in Magoon, L.B., and Dow, W.G., eds., The petroleum systemFrom source to trap: American Association of Petroleum Geologists Memoir 60, p. 93-117.

U.S. Geological Survey Uinta-Piceance Assessment Team, comps., 2003, Petroleum systems and geologic assessment of oil and gas in the Uinta-Piceance Province, Utah and Colorado (ver. 1.0) [CD-ROM]: U.S. Geological Survey Digital Data Series DDS-69-B, 51 p.

\section{Mancos Shale Assessment Team}

Sarah J. Hawkins (Task Leader, shawkins@usgs.gov), Ronald R. Charpentier, Christopher J. Schenk, Heidi M. Leathers-Miller, Timothy R. Klett, Michael E. Brownfield, Tom M. Finn, Stephanie B. Gaswirth, Kristen R. Marra, Phuong A. Le, Tracey J. Mercier, Janet K. Pitman, and Marilyn E. Tennyson

\section{For Additional Information}

Assessment information can be accessed at the USGS Energy Resources Program Web site at http://energy.usgs.gov. 